\title{
Marriage and Mortgages
}

\author{
Curtis Crawford, Yih Feng Low and Aleksander Rinaldo
}

\begin{abstract}
Using annualised data, this paper uses a regression model to help explain the relationship between home ownership, marriage, and key economic variables. By investigating the current body of knowledge this paper highlights support for two main theories that explain a fall in home ownership among those aged less than 35. Social trends, particularly delays in relationship formation (marriages), are cited by many academics as being the main reason for the decline in ownership among the young. However, there is more recent support for economic factors, suggesting affordability is much more of an issue for those who wish to achieve home ownership. The regression model, which uses home finance as a proxy for entry to home ownership, suggests that there is a statistically significant relationship between marriages and homeownership from 1979- 2010 but not between median house prices and home ownership.
\end{abstract}




\section{Introduction and Literature Review}

Home ownership has for a long time been referred to as the great Australian dream. Australia has a long history of government policies to encourage home ownership (Dungey, Wells \& Thompson 2011). Numerous benefits of homeownership have been cited to justify such policies. These range from individual comfort and security (Menzies 1942) to retirement planning (Bradbury 2010) and even positive externalities such as better social outcomes (Aaronson 2000; Rossi \& Webber 1996).

The rates of home ownership in Australia have been researched extensively by academics, particularly rates among the young which have been falling steadily for some time.

Yates (2011) suggests the 24 to 34 year age group as being an important household formation period to home ownership. According to Yates, home ownership rates for the overall population have been steady, holding around $70 \%$ for roughly the last 50 years. However, Yates suggests the greater proportion of older households owning their homes, offsets the falling rate of ownership for those younger than 35 years old. Yates cites decreased home ownership rates of 9 percentage points from 1976 to 2001 in census data.

Academics have suggested different reasons for the declining rates among the young, citing issues such as affordability, lifestyle choices, and delays in formal dual-income relationship formation -formal marriages often cited specifically. McDonald \& Baxter (2005) highlight the importance of relationship formation to achieve home ownership, specifically formal marriages which lead to dual income households. Yates (2011), suggests lifestyle factors and affordability for low income households. This previous research used differing methodology and time periods to draw these differing conclusions; however no research found debates the fact that ownership rates has fallen for this critical formation period age group of those younger than 35 years old. 
Figure 1: Home ownership rates among the young

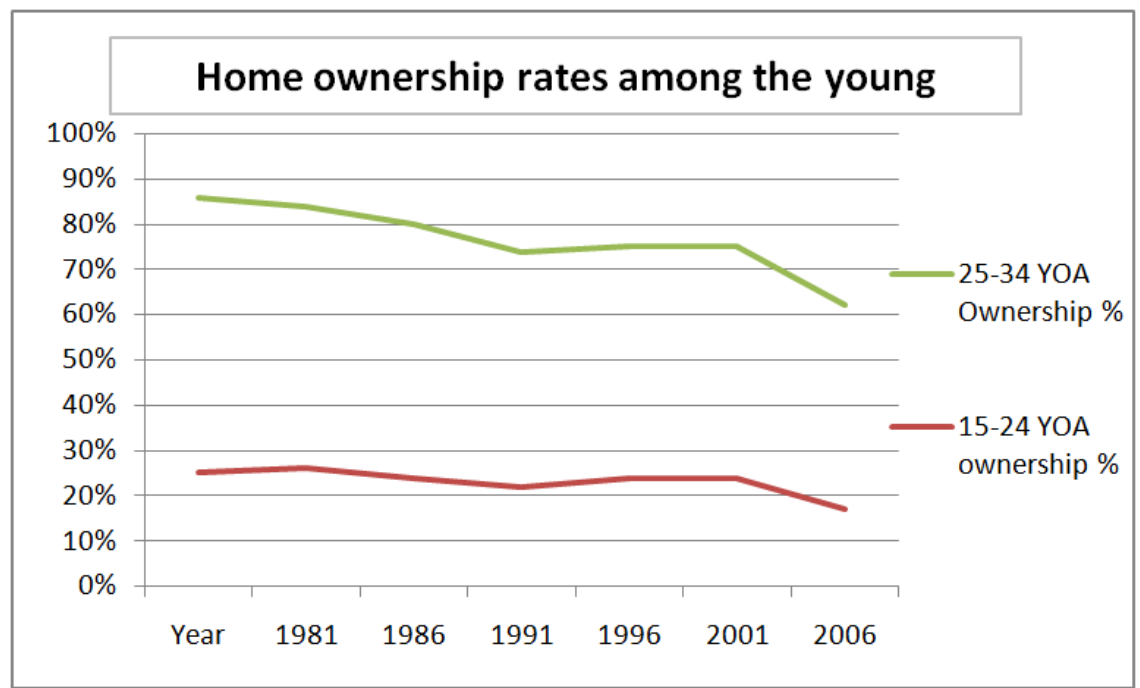

Source: Yates 2011 (p.7)

Conducting extensive research with discrete time-series analysis to the year $2000 \mathrm{McDonald}$ \& Baxter (2005), suggest that observed decreases in home ownership rates among the young are associated with delays in marriage formation. This suggests a deferral in home ownership. McDonald and Baxter suggest that if such delays result in the future to people never marrying it is possible home ownership may then fall, rather than simply being delayed. Mudd et al. (2001), broadly agree with this analysis, stating 'There is some evidence that as people progress through their life cycle the home purchase decision is being delayed. This may reflect population diversity and changes in life cycle behavioural patterns'. (Mudd et al. 2001 p. vii).

Reviewing factors that have caused the decline in home ownership among the young, Yates (2011) suggests that economic pressures (inflation, interest rate, and house prices) exacerbate the effect that social changes (decreased dual incomes, divorces, and delays in marriage 
formation)have on home ownership, the result of which is squeezing-out low income households from ownership. Yates concludes that due mainly to economic forces homeownership is in decline rather than being simply deferred and is not likely to be reversed.

Although the conclusions might seem similar, Yates (2011) conclusion suggests a decline in homeownership, particularly in low income households, where ownership is being achieved at a decreasing rate. Whereas the conclusions from McDonald \& Baxter (2005) and Mudd et al. (2001) suggest homeownership is being deferred, with no real cause for alarm. McDonald and Baxter's suggestion of ownership achievement in Australia being highly associated with a shift to dual income households through formal marriages forms the central focus of this paper. Through regression analysis this research seeks to clarify if falls in entry to home ownership among the young are attributable to falling marriage rates or are better explained by economic forces.

\subsection{Changes since the year 2000}

House prices have increased significantly in real terms since McDonald and Baxter (2005) cited relationship formation as the key variable in regards to ownership. Yates highlights further home ownership falls among those younger than 35 years of age by around 6 percentage points in the decade following the year 2000. Although crude marriage rates (registered married couples per 1000 estimated population) have also steadily declined, we suggest that these falls may not be sufficient to explain the continued falls in homeownership among the young. Consistent with the more recent conclusion of Yates (2011); economic factors have exacerbated the effects of social change, resulting in home ownership declines.

Andrews \& Sanchez (2011) suggest that a deeper understanding of the factors driving home ownership trends is useful given the potential for home ownership on economic performance. The analysis that follows seeks to clarify if formal marriages have an effect on entry to home ownership through housing finance or if economic factors, specifically median house price, are a stronger determinant of home ownership. 


\section{Hypothesis}

The hypothesis of this paper is: marriages increase aggregate home ownership in Australia.

The theory for this hypothesis is that, prior to significant real increases in median house prices in Australia from 2000 onwards, academics ( McDonald and Baxter 2005) supported the notion that the combination of a dual income relationships with a formal marriage agreements lead to greater home ownership.

Entry to home ownership in Australia through housing finance is generally the norm as suggested by the ABS (2013), 93\% of first home buyers use mortgage finance to enable the purchase. We expect this to be a good proxy for entry into home ownership as explained in the following section.

The alternate hypothesis is that marriages do not increase home ownership in Australia. The reasons for this may be that couples do not wait until marriage for purchasing a home, or because singles buy homes on their own.

\section{Analysis}

To test if a relationship between marriage and home ownership still exists, or if economic factors have become more important, regression analysis was conducted using the dependent variable 'annual owner occupied dwelling finance commitments (mortgages)' with marriage and economic variables as independent variables. Previous support for marriage being included in such analysis has already been discussed. On an economic basis the following variables will be used in the proceeding analysis:

New housing finance for owner occupiers (re-financing omitted) as proxy for entry into home ownership. The benefits of using new owner occupier finance as proxy are that it is frequent (monthly, annual) and it provides the quantity of new finance commitments, excluding re-financing, for owner occupied dwellings. 
Figure 2: Key Variable Matrix*

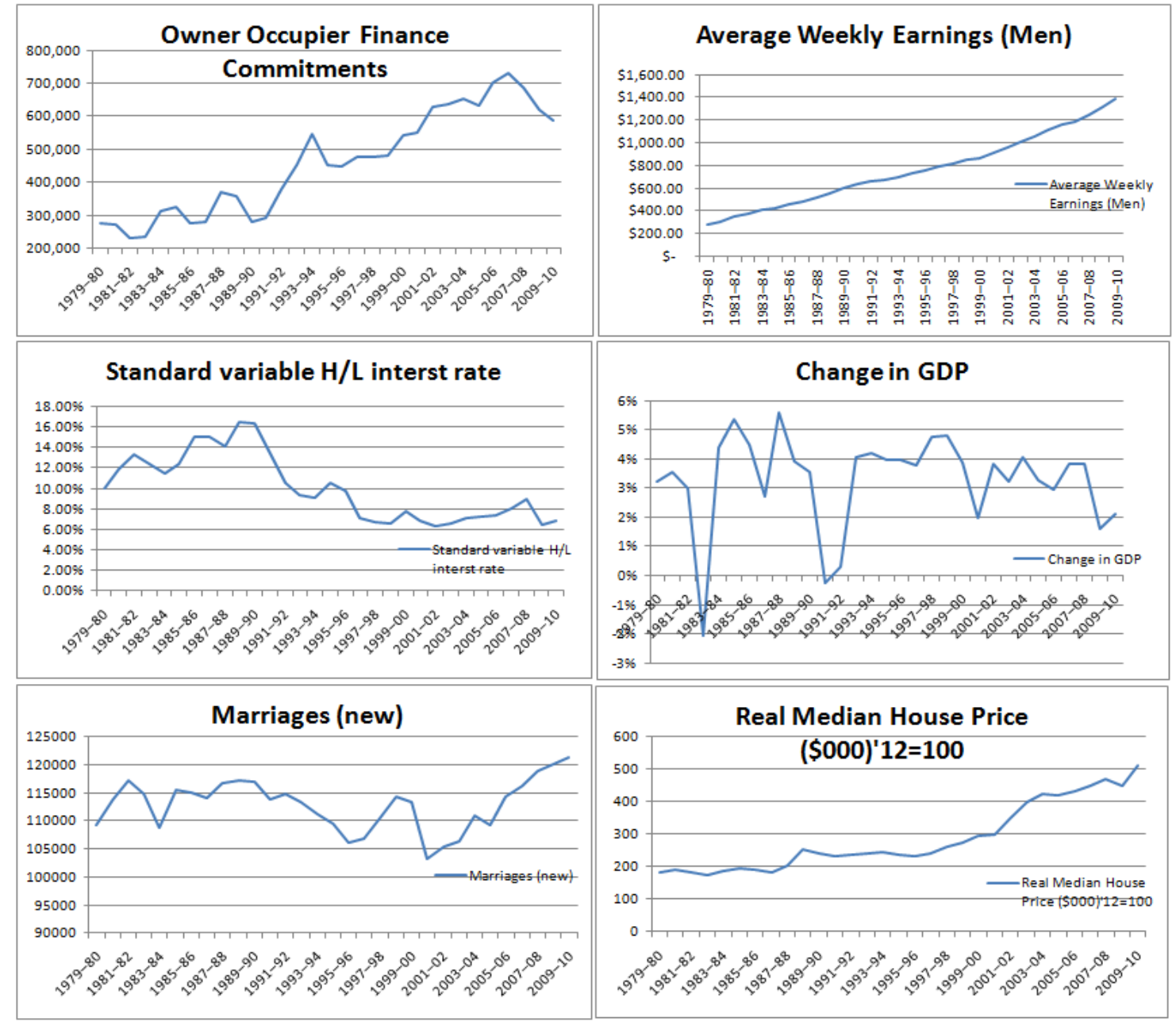

*Standard Variable H/L interest rate data obtained from Loan sense (2013). Real Median House Prices, and average weekly earnings data, to year 2003 obtained from Stapledon (2007). All Other data obtained from ABS (2013). 
Change in GDP/ Average Weekly Earnings are used as a measure of economic wellbeing. Prevailing economic conditions is expected to exert an influence on major economic decisions such as buying a home. Paris (cited in Bourassa, Greig \& Troy 1995) identified economic growth as a key driving force in promoting widespread home ownership in Australia since the Second World War.

Since the average home buyer enters the market by way of finance, the prevailing price of financing would have an effect on housing demand as per standard demand/supply analysis. Interest Rates have been empirically shown to be an important variable influencing housing market dynamics (Tsatsaronis \& Zhu 2004).

Population Growth can drive homeownership dynamics in several ways. All else being equal, population growth, through immigration and birth should increase demand for home ownership.

Standard demand/supply analysis suggests as the price of housing increases, the quantity of housing demanded falls. It would thus be expected that Real Median House Prices, which have risen significantly over the past two decades, have a significant influence over homeownership rates through increasing affordability constraints.

\subsection{Regression Model}

To find a model that explains a large proportion of the changes in the amount of new owner occupier housing finance many regressions and correlation matrices were analysed resulting in the following regression model.

Surprisingly variables such as median house price and population growth had no statistical significance in explaining the amount of dwellings financed and were removed in the order of their insignificance. Similar was done with the different marriage lags/leads to achieve this regression (please see Appendix B for process of removing insignificant variables). 
Table 1: Final regression on dwellings financed

\begin{tabular}{|c|c|c|c|c|}
\hline \multicolumn{5}{|c|}{ Model Summary } \\
\hline Model & $\mathrm{R}$ & R Square & $\begin{array}{l}\text { Adjusted R } \\
\text { Square }\end{array}$ & $\begin{array}{l}\text { Std. Error of the } \\
\text { Estimate }\end{array}$ \\
\hline 1 & $.980^{\mathrm{a}}$ & .960 & .944 & 30074.76164 \\
\hline
\end{tabular}

a. Predictors: (Constant), Lag(Marriages,4), C.GDP, Lag(Marriages,2), Lead(Marriages,5), Interestrate, Earnings

Coefficients $^{\mathrm{a}}$

\begin{tabular}{|c|c|c|c|c|c|c|c|}
\hline \multirow[b]{2}{*}{ Model } & & \multicolumn{3}{|c|}{ Unstandardized Coefficients } & \multirow{2}{*}{$\begin{array}{c}\begin{array}{c}\text { Standardized } \\
\text { Coefficients }\end{array} \\
\text { Beta }\end{array}$} & \multirow[b]{2}{*}{$t$} & \multirow[b]{2}{*}{ Sig. } \\
\hline & & & B & Std. Error & & & \\
\hline \multirow[t]{7}{*}{1} & (Constant) & & -1602063.458 & 488371.608 & & -3.280 & .005 \\
\hline & Change in GDP & & 1901863.676 & 613208.410 & .211 & 3.101 & .007 \\
\hline & Interest Rate & & -11885.377 & 3449.929 & -.328 & -3.445 & .004 \\
\hline & Average Weekly Earnings & & 10.054 & 1.434 & .853 & 7.010 & .000 \\
\hline & Lead(Marriages,5) & +1 & 4.438 & 1.462 & .175 & 3.036 & .008 \\
\hline & Lag(Marriages,2) & & 6.396 & 2.523 & .218 & 2.535 & .023 \\
\hline & Lag(Marriages,4) & & 4.514 & 2.020 & .140 & 2.235 & .041 \\
\hline
\end{tabular}

a. Dependent Variable: Dwellings

*To see how this model was achieved through removal of insignificant variables please refer to Appendix B.

\subsection{Results}

The test of significance of the overall regression model (F-test)

Table 2: Sum of squares

\begin{tabular}{|l|r|r|r|r|r|r|}
\hline & & & & \\
Model & Sum of Squares & df & Mean Square & Sig. \\
\hline 1 & Regression & 322628207191.368 & 6 & 53771367865.228 & 59.449 & $.000^{b}$ \\
& Residual & 13567369314.087 & 15 & 904491287.606 & & \\
& Total & 336195576505.455 & 21 & & & \\
\hline
\end{tabular}

a. Dependent Variable: Dwellings

b. Predictors: (Constant), Lag(Marriages,4), C.GDP, Lag(Marriages,2), Lead(Marriages,5), Interestrate, Earnings 
In order to test if the relationship is significant between dwellings financed (the dependent variable) and the independent variables in the regression an F-test was conducted.

$$
H_{0}=\beta_{1}=\beta_{2}=\cdots=\beta_{k}=0
$$

The above null hypothesis states that none of the independent variables significantly affect Dwellings financed.

$$
H_{1}=\beta_{1}, \beta_{2}, \ldots, \beta_{k} \neq 0
$$

The above null hypothesis states that at least one of the independent variables are significantly different from zero.

$$
\mathrm{F}=\frac{\frac{\text { Explained variation }}{\mathrm{k}}}{\frac{\text { Unexplained variation }}{\mathrm{n}-(\mathrm{k}+1)}}=\frac{\frac{322628207191.4}{6}}{\frac{13567369314.1}{22-(6+1)}}=59.449
$$

The critical value at a 0.01 significant level is $6.36 . \mathrm{H}_{0}$ would be rejected if $\mathrm{F}>6.36$ and since $59.449>6.36$ the $\mathrm{H}_{0}$ is rejected, indicating that at least one of the independent variables is significantly related to the dependent variable. Therefore the overall model cannot be rejected in terms of significance.

Change in GDP, Interest Rates, average weekly earnings and marriages (leading 5 years and lagging marriages two and four years) have a statistically significant relationship with the amount of new mortgages. Lead marriages (5 years) suggest some cohabitation, facilitated by mortgages, prior to marriage.

With the variable 'lag marriages 2'(read 'marriages lagging two years') each marriage that occurs two years in the past seems to correlate with 6.396 dwellings financed in this financial year. Similarly, 'lead marriages 5' and 'lag marriages 4' have a positive relationship with dwellings financed, with beta coefficients of 4.4 and 4.5 respectively. Clearly one new marriage 
cannot lead to more than one new dwelling financed - the large coefficients reflect that the data has not been detrended. This is also true for the earnings variable.

Although increases in real median house prices have been witnessed since McDonald and Baxter (2005) concluded their analysis -to year 2000, the national aggregated annual median house price did not explain falls in owner occupied dwelling finance to the year 2010. The analysis therefore supports McDonald and Baxter's conclusions. In regards to Yates' (2011) conclusions, this model suggests that median house prices, no doubt a major component of affordability, are not a significant determinant in home ownership if you view housing finance as a reliable proxy for this. However, our use of national aggregates of median house prices potentially down-plays the effect that affordability has. Affordability may only be an issue in some states, or over certain price ranges.

\section{Conclusion}

Marriages seem to have a higher correlation with mortgages, and therefore possibly home ownership, than that of aggregated annual median house prices, as this variable was removed quite early in the analysis as outlined in Appendix B. Marriages cannot be removed as insignificant from this model and we accept the analysis from McDonald and Baxter (2005) that marriages are an important determinant for home ownership. However, we urge caution in concluding such affordability factors do not significantly explain falling home ownership level among the young, as outlined in the following section.

\subsection{Limitations}

We recognise the limitations of the regression model. The proxy of finance commitments for home ownership has two major downfalls. 1) it reports total finance (units) for all mortgages, rather than all new borrowers. The quantity will no doubt include individual re-entering home ownership through a mortgage other than their first mortgage (different to re-financing which 
was excluded from the variable). The proxy also does not exclude those older than 35 years of age.

Cohabitation prior to marriage, (de-facto relationships) are not taken into account as there is no annual data available for the time period researched. However, the significance of the 5 year lead marriage rate suggests that some people may purchase a home prior to getting married. Clearly de-facto relationships need to be taken into account before the total effect formal marriages have on home ownership is recognised.

First home owner grants and net government assistance were also omitted from this regression model. Figures were collected for the 2000 to 2010 years, however assistance varied on a quarterly basis and from state to state. A similar report using quarterly frequency (at a minimum) at a state level would be better able to recognise the effect of these policies.

The results from this report, although inconclusive when considering the above limitations, should encourage further analysis focused on individual states and their capital cities, rather than national aggregates. As more data becomes available, particularly for measuring entry to home ownership (such as the 'Negotiating the Life Course survey' by the Australian National University) at a state level this model could be further developed with greater reliability, to help analyse the determinants of home ownership among the young, ensuring home ownership is possible as social and economic trends continue to change over time. 


\section{References}

Aaronson, D 2000, 'A Note on the Benefits of Homeownership', Journal of Urban Economics, Vol. 47, No. 3, pp. 356-369.

Andrews, D, \& Sánchez, A 2011, 'The Evolution of Homeownership Rates in Selected OECD Countries: Demographic and Public Policy Influences', OECD Journal: Economic Studies, 2011, 1, pp. 207-243, Business Source Complete, EBSCOhost, viewed 1 April 2013.

Australian Bureau of Statistics, 2013, 5206.0 - Australian National Accounts: National Income, Expenditure and Product-data, retrieved 19 April 2013, < http://www.abs.gov.au/AUSSTATS/ abs@.nsf/DetailsPage/5206.0Dec\%202012?OpenDocument>.

Australian Bureau of Statistics, 2013, 6401.0 - Consumer Price Index, Australia-data, retrieved 19 April 2013, <

http://www.abs.gov.au/AUSSTATS/abs@.nsf/DetailsPage/6401.0Mar\%202013?OpenDocume nt>.

Australian Bureau of Statistics, 2013, 'Home Buyers' viewed 31

March2013<http://www.abs.gov.au/ausstats/abs@.nsf/Lookup/by\%20Subject/1301.0 2012 M ain\%20Features $\sim$ Home\%20Buyers 131>

Australian Bureau of Statistics, 2013, 5609.0 - Housing Finance, Australia-data, retrieved 19 April 2013, <http://www.abs.gov.au/AUSSTATS/abs@.nsf/DetailsPage/5609.0Jan\%202013?OpenDocume nt>.

Australian Bureau of Statistics, 2013, 3310.0 - Marriages and Divorces, Australia-data, retrieved 19 April 2013, <

http://www.abs.gov.au/AUSSTATS/abs@.nsf/DetailsPage/3310.02011?OpenDocument>. 
Australian Bureau of Statistics, 2013, 5206.0 - 6416.0 - House Price Indexes: Eight Capital Cities, Sep 2010 -data, retrieved 19 April 2013, <ttp://www.abs.gov.au/AUSSTATS/abs@.nsf/DetailsPage/6416.0Sep\%202010>.

Australian Bureau of Statistics, 2013, Population Growth -data, retrieved 19 April 2013, <http://www.abs.gov.au/AUSSTATS/abs@.nsf/DetailsPage/3105.0.65.0012008?OpenDocume nt $>$.

Bourassa, S, Greig, A, \& al, e 1995, 'The limits of housing policy: Home ownership in Australia', Housing Studies, 10, 1, p. 83, Academic Search Complete, EBSCOhost, viewed 30 April 2013. $<$ http://ehis.ebscohost.com/ehost/detail?sid=4f4db631-59b2-468a-a47f3fa4d7bdcc28\%40sessionmgr10\&vid=1\&hid=5\&bdata=JnNpdGU9ZWhvc3QtbGl2ZSZzY29 wZT1zaXRl\#db=a9h\&AN=9503223326>.

Bradbury, B 2010, 'Asset rich, but income poor: Australian housing wealth and retirement in an international context', Social Policy Research Paper No. 41, Social Policy Research Centre, Australian Government Department of Families, Housing, Community Services and Indigenous Affairs.

Dungey, D Wells, G \& Thompson S 2011, First Home Buyers’ Support Schemes in Australia, The Australian Economic Review, vol. 44, no. 4, pp. 468-79, retrieved 25 ${ }^{\text {th }}$ April 2013, $<$ http://www.utas.edu.au/_data/assets/pdf_file/0014/205061/DP2011_01_First-home-buyerssupport-schemes-across-Australia-SamEdits5.pdf $>$.

Loan Sense, 2013, 'Standard Variable Home Loan Interest Rates 1959 - 2013 Australia’, Loan sense, viewed 19 April 2013, <http://www.loansense.com.au/historical-rates.html>.

McDonald, P and Baxter, J and, 2005, 'Home Ownership among young people in Australia: in decline or just delayed?’, Australian Journal of Social Issues, Vol. 40, No. 4, 471-487. viewed 31 March 2013. 
Menchaca, P 2010, 'What's Next for Real Estate', Financial Planning, 40, 10, pp. 100-103, Business Source Complete, EBSCOhost, retrieved 28 April 2013.

Menzies, R 1942, 'The Forgotten People - Speech by Robert Menzies on 22 May, 1942. Liberals.Net: Liberal Party of Australia', retrieved $4^{\text {th }}$ May 2013, $<$ http://www.liberals.net/theforgottenpeople.htm>.

Mudd, W, Tesfaghiorghis, H and Bray, RJ, 2001, Policy Research Paper No. 17: Some issues inhome ownership, Department of Family and Community Services Australia, retrieved $7^{\text {th }}$ April 2013, 〈http://www.housing.infoxchange.net.au/library/ahin/homeownership/items/00030-upload00001.pdf〉.

Reserve Bank of Australia 2013, 'RBA: Minutes of Monetary Policy Meeting of the Board-5 February 2013’, retrieved 4th May 2013, <http://www.rba.gov.au/monetary-policy/rba-boardminutes/2013/05022013.html>.

Rossi, P \& Weber, E 1996, 'The social benefits of homeownership: Empirical evidence from national surveys’, Housing Policy Debates, Vol. 7, No. 1, pp. 1-35. Viewed May 32013 < http://content.knowledgeplex.org/kp2/ img/cache/documents/1374.pdf>.

Stapledon, N 2007, Long Term Housing Prices in Australia and Some Economic Perspectives, The University of New South Wales, retrieved 30 April 2013,<http://www.apialliance.com.au/articles/Long\%20Term\%20Housing\%20Prices\%20in\%2 0Australia\%20-\%20Stapleton\%20UNSW.pdf>.

Yates, J 2011, 'Explaining Australia's trends in home ownership', Housing Finance International, 26, 2, pp. 6-13, Business Source Complete, EBSCOhost, viewed 31 March 2013. 


\section{Appendix A- Data *}

\begin{tabular}{|c|c|c|c|c|c|c|c|c|}
\hline Year & $\begin{array}{r}\text { Occupier } \\
\text { Finance } \\
\text { commitments } \\
\end{array}$ & $\begin{array}{r}\text { Marriages } \\
(\text { new) }\end{array}$ & $\begin{array}{c}\text { Change } \\
\text { in GDP }\end{array}$ & $\begin{array}{r}\text { Standard } \\
\text { variable } \mathrm{H} / \mathrm{L} \\
\text { interst rate }\end{array}$ & $\begin{array}{r}\text { Average } \\
\text { Weekly } \\
\text { Earnings (Men) } \\
\end{array}$ & \begin{tabular}{|r|} 
Population \\
Growth \\
\end{tabular} & $\begin{array}{r}\text { Real Median } \\
\text { House Price } \\
(\$ 000) ' 12=100\end{array}$ & $\begin{array}{r}\% \\
\text { Change } \\
\text { in CPI }\end{array}$ \\
\hline $1979-80$ & 276,297 & 109240 & $3 \%$ & $9.98 \%$ & 280.54 & 14695.4 & 180.9160305 & 0 \\
\hline 1980-81 & 271,696 & 113905 & $4 \%$ & $11.83 \%$ & 306.65 & 14923.3 & 191.9014085 & $8.40 \%$ \\
\hline 1981-82 & 228,972 & 117275 & $3 \%$ & $13.29 \%$ & 351.79 & 15184.2 & 183.1746032 & $10.92 \%$ \\
\hline 1982-83 & 234,248 & 114860 & $-2 \%$ & $12.42 \%$ & 374.40 & 15393.5 & 173.4285714 & $11.11 \%$ \\
\hline 1983-84 & 314,485 & 108655 & $4 \%$ & $11.50 \%$ & 405.94 & 15579.4 & 188.1868132 & $4.00 \%$ \\
\hline $1984-85$ & 323,497 & 115493 & $5 \%$ & $12.42 \%$ & 427.75 & 15788.3 & 192.7835052 & $6.59 \%$ \\
\hline $1985-86$ & 275,861 & 114913 & $4 \%$ & $15.00 \%$ & 455.31 & 16018.4 & 190.736342 & $8.51 \%$ \\
\hline 1986-87 & 279,338 & 114113 & $3 \%$ & $15.08 \%$ & 487.48 & 16263.9 & 182.3913043 & $9.26 \%$ \\
\hline $1987-88$ & 371,738 & 116816 & $6 \%$ & $14.08 \%$ & 518.90 & 16532.2 & 202.0283976 & $7.17 \%$ \\
\hline 1988-89 & 359,668 & 117176 & $4 \%$ & $16.46 \%$ & 559.50 & 16814.4 & 54.0943396 & $7.51 \%$ \\
\hline 1989-90 & 280,071 & 116959 & $4 \%$ & $16.35 \%$ & $\$ \quad 598.60$ & 17065.1 & 239.6322242 & $7.74 \%$ \\
\hline 1990-91 & 293,721 & 113869 & $0 \%$ & $13.42 \%$ & 632.73 & 17284.0 & 233.3728814 & $3.33 \%$ \\
\hline 1991-92 & 379,306 & 114752 & $0 \%$ & $10.58 \%$ & 655.90 & 17494.7 & 236.4656616 & $1.19 \%$ \\
\hline 1992-93 & 453,138 & 113255 & $4 \%$ & $9.42 \%$ & 672.60 & 17667.1 & 238.7006579 & $1.84 \%$ \\
\hline 1993-94 & 544,485 & 111174 & $4 \%$ & $9.09 \%$ & 695.67 & 17854.7 & 242.7948304 & $1.81 \%$ \\
\hline 1994-95 & 451,348 & 109386 & $4 \%$ & $10.50 \%$ & 729.31 & 18071.8 & 236.25966 & $4.52 \%$ \\
\hline 1995-96 & 449,512 & 106103 & $4 \%$ & $9.73 \%$ & 761.90 & 18310.7 & 231.904048 & $3.09 \%$ \\
\hline 1996-97 & 477,359 & 106735 & $4 \%$ & $7.17 \%$ & 787.42 & 18517.6 & 238.6696562 & $0.30 \%$ \\
\hline $1997-98$ & 476,642 & 110598 & $5 \%$ & $6.68 \%$ & 819.63 & 18711.3 & 260.4005935 & $0.75 \%$ \\
\hline 1998-99 & 481,694 & 114316 & $5 \%$ & $6.57 \%$ & 846.08 & 18925.9 & 274.4346549 & $1.04 \%$ \\
\hline 1999-00 & 542,152 & 113429 & $4 \%$ & $7.72 \%$ & 868.63 & 19153.4 & 292.7492877 & $3.08 \%$ \\
\hline $2000-01$ & 550,820 & 103130 & $2 \%$ & $6.84 \%$ & 906.40 & 19413.2 & 298.7785235 & $6.13 \%$ \\
\hline 2001-02 & 629,567 & 105435 & $4 \%$ & $6.36 \%$ & 954.13 & 19651.4 & 350.0522193 & $2.82 \%$ \\
\hline $2002-03$ & 634,935 & 106394 & $3 \%$ & $6.61 \%$ & $1,006.31$ & 19895.4 & 398.1043257 & $2.61 \%$ \\
\hline 2003-04 & 651,630 & 110958 & $4 \%$ & $7.05 \%$ & $1,058.17$ & 20127.4 & 423.101737 & $2.54 \%$ \\
\hline $2004-05$ & 630,951 & 109323 & $3 \%$ & $7.26 \%$ & $1,110.35$ & 20394.8 & 420.9927361 & $2.48 \%$ \\
\hline $2005-06$ & 700,673 & 114222 & $3 \%$ & $7.40 \%$ & $1,158.38$ & 20697.9 & 431.6181607 & $4.00 \%$ \\
\hline $2006-07$ & 730,399 & 116322 & $4 \%$ & $8.03 \%$ & $1,183.65$ & 21015.9 & 449.2366021 & $2.10 \%$ \\
\hline $2007-08$ & 683,968 & 118756 & $4 \%$ & $9.00 \%$ & $1,243.45$ & 21384.4 & 469.5884279 & $4.45 \%$ \\
\hline $2008-09$ & 622,167 & 120118 & $2 \%$ & $6.42 \%$ & $1,310.68$ & 21778.8 & 448.320775 & $1.42 \%$ \\
\hline 2009-10 & 586,463 & 121176 & $2 \%$ & $6.86 \%$ & $1,383.63$ & 22065.3 & 510.7202505 & $3.12 \%$ \\
\hline
\end{tabular}

*Standard Variable H/L interest rate data obtained from Loan sense (2013). Real Median House Prices data obtained from Stapledon (2007). All Other data obtained from ABS (2013). 
Real median house prices calculated using CPI index (ABS 2013) and data from Stapledon (2007, pp 64-65 ) to year 2003 followed by comparable median house price data from the ABS (2013).

Historic Average Weekly Earnings (male adults), obtained from Stapledon (2007, Table B.6).

\section{Appendix B - Working towards a regression model to explain Annual Owner Occupier Finance Commitments.}

Insignificant variables highlighted in red.

\section{B1 Working towards first significant model (Less Marriages).}

\section{i}

Coefficients $^{a}$

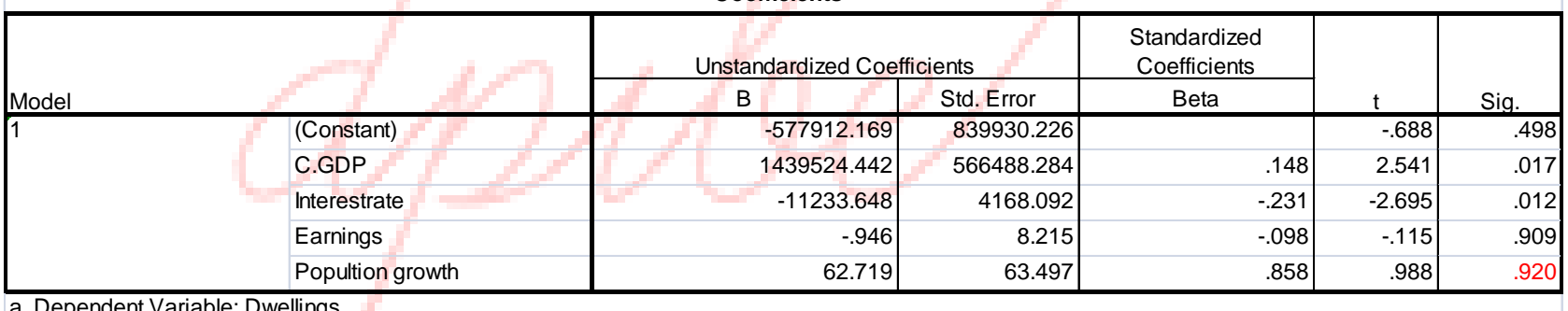

a. Dependent Variable: Dwellings

ii

\begin{tabular}{|c|c|c|c|c|c|c|}
\hline \multicolumn{7}{|c|}{ Coefficients $^{\mathrm{a}}$} \\
\hline \multirow[b]{2}{*}{ Model } & & \multicolumn{2}{|c|}{ Unstandardized Coefficients } & \multirow{2}{*}{$\begin{array}{c}\begin{array}{c}\text { Standardized } \\
\text { Coefficients }\end{array} \\
\text { Beta }\end{array}$} & \multirow[b]{2}{*}{$\mathrm{t}$} & \multirow[b]{2}{*}{ Sig. } \\
\hline & & B & Std. Error & & & \\
\hline \multirow[t]{5}{*}{1} & (Constant) & 256209.064 & 79225.836 & & 3.234 & .003 \\
\hline & C.GDP & 1373871.549 & 607182.451 & 145 & 2.263 & .033 \\
\hline & Interestrate & -12425.111 & 4328.042 & -.262 & -2.871 & .008 \\
\hline & Earnings & 7.006 & .901 & .714 & 7.774 & .000 \\
\hline & C.Real.MHP & 118097.236 & 138116.607 & .055 & .855 & .401 \\
\hline
\end{tabular}




\section{B2 First Significant Model}

\begin{tabular}{|c|c|c|c|c|c|c|}
\hline \multicolumn{7}{|c|}{ Coefficients $^{a}$} \\
\hline \multirow[b]{2}{*}{ Model } & & \multicolumn{2}{|c|}{ Unstandardized Coefficients } & \multirow{2}{*}{$\begin{array}{c}\begin{array}{c}\text { Standardized } \\
\text { Coefficients }\end{array} \\
\text { Beta }\end{array}$} & \multirow[b]{2}{*}{$\mathrm{t}$} & \multirow[b]{2}{*}{ Sig. } \\
\hline & & $\mathrm{B}$ & Std. Error & & & \\
\hline \multirow[t]{4}{*}{1} & (Constant) & 248755.749 & 70896.540 & & 3.509 & .002 \\
\hline & C.GDP & 1563787.187 & 552092.925 & .161 & 2.832 & .009 \\
\hline & Interestrate & -12372.830 & 4003.542 & -.255 & -3.090 & .005 \\
\hline & Earnings & 7.130 & .793 & .740 & 8.988 & .000 \\
\hline
\end{tabular}

\section{B3Working towards second significant model (including marriages)}

\section{B3.i}

\begin{tabular}{|c|c|c|c|c|c|c|c|}
\hline \multicolumn{8}{|c|}{ Coefficients $^{a}$} \\
\hline Model & & \multicolumn{3}{|c|}{ Unstandardized Coefficients } & $\begin{array}{c}\text { Standardized } \\
\text { Coefficients } \\
\end{array}$ & $\mathrm{t}$ & Sig. \\
\hline \multirow[t]{13}{*}{1} & (Constant) & & 47.341 & 1753849.438 & & -1.399 & .211 \\
\hline & C.GDP & $t_{1}-$ & 98.811 & 1136704.729 & .256 & 1.984 & .094 \\
\hline & Interestrate & & 86.476 & 12367.128 & -.552 & -1.576 & .166 \\
\hline & Marriages & & -.746 & 5.100 & -.025 & -.146 & .888 \\
\hline & Lead(Marriages,1) & & .120 & 5.450 & .004 & .022 & .983 \\
\hline & Lead(Marriages,2) & & 1.857 & 4.787 & .062 & .388 & .711 \\
\hline & Lead(Marriages,3) & & -.282 & 5.020 & -.010 & -.056 & .957 \\
\hline & Lead(Marriages,4) & & 2.781 & 5.825 & .104 & .477 & .650 \\
\hline & Lead(Marriages,5) & & 3.020 & 4.177 & .119 & .723 & .497 \\
\hline & Lag(Marriages,2) & & 6.056 & 5.145 & .205 & 1.177 & .284 \\
\hline & Lag(Marriages,3) & & 1.682 & 4.141 & .057 & .406 & .699 \\
\hline & Lag(Marriages,4) & & 6.226 & 4.814 & .195 & 1.293 & .243 \\
\hline & Lag(Marriages,5) & & -2.510 & 3.883 & -.067 & -.646 & .542 \\
\hline
\end{tabular}




\section{B.3ii}

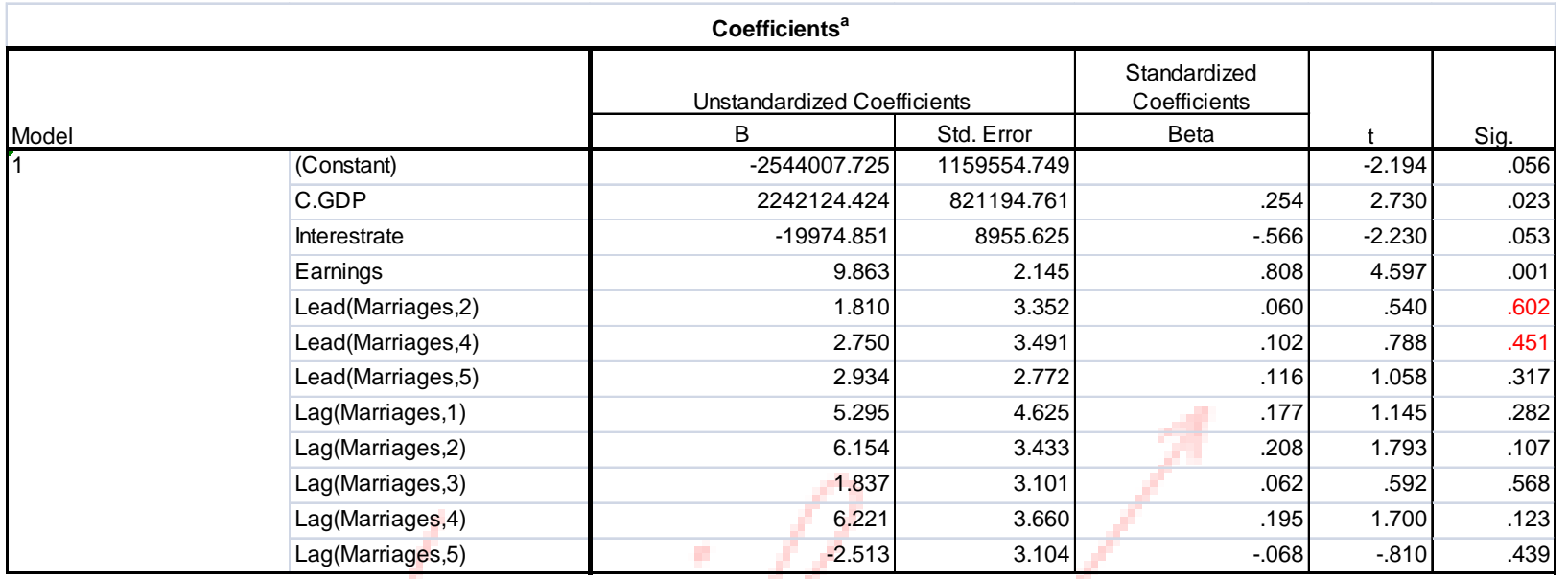

\section{B3.iii}

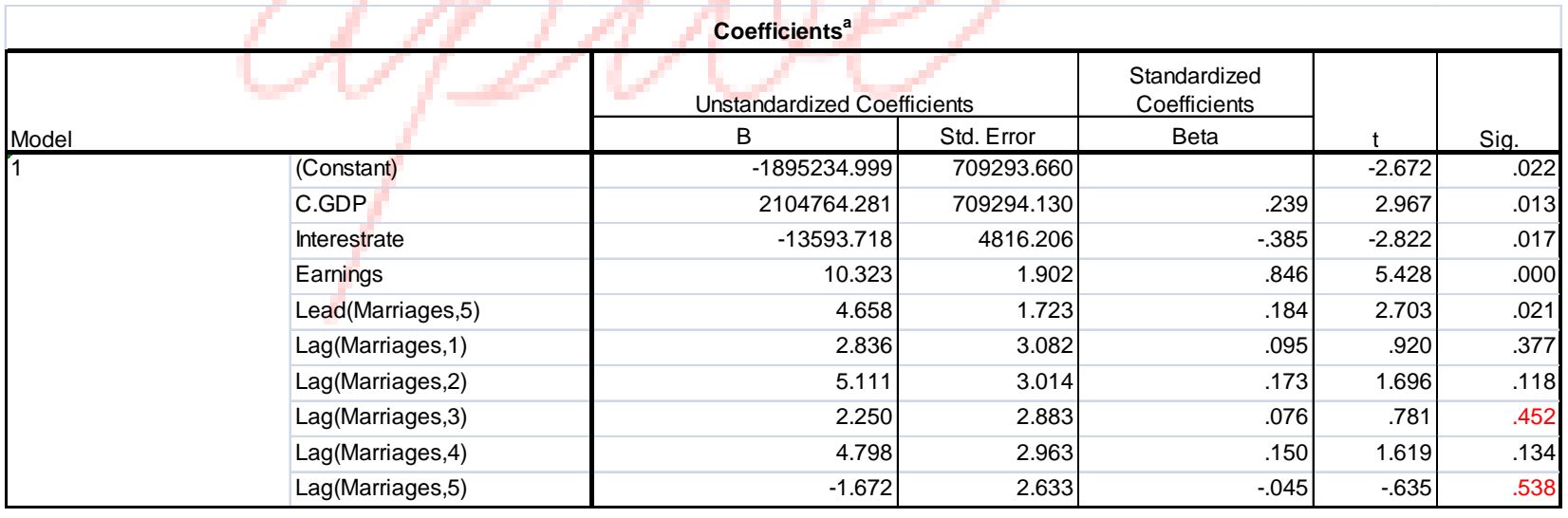




\section{B3.iv}

\begin{tabular}{|c|c|c|c|c|c|c|}
\hline \multicolumn{7}{|c|}{ Coefficients $^{a}$} \\
\hline \multirow[b]{2}{*}{ Model } & & \multicolumn{2}{|c|}{ Unstandardized Coefficients } & \multirow{2}{*}{$\begin{array}{c}\text { Standardized } \\
\text { Coefficients }\end{array}$} & \multirow[b]{2}{*}{$\mathrm{t}$} & \multirow[b]{2}{*}{ Sig. } \\
\hline & & B & Std. Error & & & \\
\hline \multirow[t]{8}{*}{1} & (Constant) & -1836411.396 & 629108.995 & & -2.919 & .011 \\
\hline & C.GDP & 2024758.281 & 657873.225 & .225 & 3.078 & .008 \\
\hline & Interestrate & -13179.884 & 4111.239 & -.364 & -3.206 & .006 \\
\hline & Earnings & 10.147 & 1.473 & .861 & 6.889 & .000 \\
\hline & Lead(Marriages,5) & 4.561 & 1.507 & .179 & 3.027 & .009 \\
\hline & Lag(Marriages,1) & 1.688 & 2.761 & .056 & 611 & .551 \\
\hline & Lag(Marriages,2) & 6.233 & 2.591 & .213 & 2.406 & .031 \\
\hline & Lag(Marriages,4) & 5.006 & 2.215 & .155 & 2.261 & .040 \\
\hline
\end{tabular}

